\title{
Pemberdayaan Kesehatan Melalui Pelatihan Pengolahan Jajanan Sehat, Bergizi, dan Aman Berbasis Pangan Lokal
}

Oleh:

Mauren Gita Miranti ${ }^{1}$, Niken Purwidiani², Ita Fatkhur Romadhoni ${ }^{1}$, Rita Ismawati ${ }^{3}$

1 Prodi Pendidikan Tata Boga Jurusan PKK, Unesa

maurenmiranti@unesa.ac.id

\begin{abstract}
Abstrak
Beredarnya pangan yang tidak aman sangat berdampak buruk pada pertumbuhan anak pada usia sekolah. Kondisi lingkungan sekolah di sekitar desa Sedayulawas, Lamongan banyak terdapat penjual dengan kualitas makanan yang kurang baik. Hal ini dapat dilihat penggunaan pewarna makanan yang sangat mencolok atau minyak goreng yang sudah tidak layak pakai. Berdasarkan hal tersebut, perlu diadakan penyuluhan pemberdayaan kesehatan mengenai pemilihan dan pelatihan pembuatan jajanan sehat dan bergizi dengan menggunakan bahan pangan lokal. Kegiatan ini ber tujuan memberikan bekal pengetahuan, sikap dan keterampilan kepada peserta pelatihan untuk mengolah jajanan berbasis pangan lokal dan meningkatkan kesadaran masyarakat terhadap keamanan pangan yang berdar. Dalam kegiatan ini dilakukan pengukuran pengetahuan sebelum dan sesudah intervensi (pre-post test). Intervensi yaitu penyuluhan dan pelatihan pembuatan jajanan. Peserta mengalami peningkatan pengetahuan mengenai jajanan sehat sebesar $14,26 \%$. Setelah itu dilakukan pelatihan pembuatan jajanan sehat dan bergizi berbasis pangan lokal. Sebesar $87,8 \%$ menyukai metode praktik langsung, dan nilai rata-rata produk yang dibuat adalah 3,45 yang terdiri dari penilaian kriteria hasil produk, sanitasi dan hygiene, serta penyajian produk. Dari kegiatan pelatihan ini dapat disimpulkan bahwa pemberdayaan kesehatan melalui pelatihan pengolahan jajanan sehat, bergizi, dan aman sangat dibutuhkan dan perlu didukung oleh masyarakat dan pemerintah melalui kebijakan/peraturan atau melalui kegiatan serupa.
\end{abstract}

Kata kunci: pemberdayaan kesehatan, pelatihan, jajanan sehat, pangan lokal

The circulation of unsafe food has a bad impact on the growth of children at school age. The condition of the school environment around the village of Sedayulawas, Lamongan, there are many sellers with poor food quality. It can be seen that the use of food coloring is very striking or cooking oil that is not suitable for use. Therefore, there is a need for counseling on health empowerment regarding the selection and training of making healthy and nutritious snacks using local food. The purpose of this activity is to provide knowledge, attitudes, and skills to trainees to process local food-based snacks and increase public awareness of food security. In this activity, a measurement of knowledge was carried out before and after the intervention (pre-post test). Interventions in the form of counseling and training in making snacks. Participants experienced an increase in knowledge about healthy snacks by $14.26 \%$. After that, a local food-based healthy and nutritious snack-making training was conducted. $87.8 \%$ liked the direct practice method, and the average value of the product made was 3.45 which consisted of evaluating the criteria for product yield, sanitation and hygiene, and product presentation. From this training activity, it can be concluded that health empowerment through training in healthy, nutritious and safe snacks processing is needed and needs to be supported by the community and the government through policies/regulations or through similar activities.

Keywords: health empowerment, training, healthy snacks, local food

\section{PENDAHULUAN}

Konteks pasar anak di Indonesia identik dengan aktifitas jajan di sekolah. Oleh sebabnya diperlukan perhatian khusus mengenai keamanan pangan jajanan yang beredar disekolah maupun dilingkuman 
rumah, karena memiliki peran dalam tumbuh kembang anak. Konsumsi jajanan di sekolah menjadi kegiatan umum yang dilakukan anakanak di Indonesia. Kondisi tersebut diperkuat oleh temuan bahwa sebagian besar sekolah memperbolehkan pedagang makanan menjajakan makanannya dilingkungan sekolah, baik itu dikantin atau pun didepan sekolah. Makanan yang berpotensi menjadi sumber keracunan adalah makanan ringan atau jajanan, karena umumnya makanan ini merupakan hasil produksi industri makanan rumahan yang kurang dapat menjamin kualitas produk olahannya (Adriani dan Wirjatmadi, 2012). Misalnya saja jajanan telur gulung yang menggunakan minyak jelantah (minyak berkali-kali pakai), minuman soda yang konsumen tidak tahu kadaluarsanya, atau makanan yang menggunakan sauce dengan warna yang mencolok.

Kondisi saat ini, jajanan yang semestinya dapat memenuhi kebutuhan gizi anak telah tercemar oleh penggunaan bahan tambahan pangan (BTP) berbahaya. Badan Pengawas Obat dan Makanan (BPOM) pada tahun 2006-2010 menemukan 48\% jajanan anak di sekolah mengandung bahan kimia yang berbahaya. BTP yang ditemukan pada jajanan sekolah telah melebihi batas yang diizinkan, belum lagi dengan adanya temuan cemaran mikrobiologi pada jajanan. Sampel jajanan yang diambil dari 6 kota, yaitu Jakarta, Serang, Bandung, Semarang, Yogyakarta, dan Surabaya, menunjukkan $72,08 \%$ positif mengandung zat berbahaya (BPOM RI, 2011). Menurut Handayani dkk (2018) berdasarkan Laporan Akhir Monitoring dan Verifikasi Profil Keamanan Pangan Jajanan Anak Sekolah (PJAS) Nasional tahun 2008 menunjukkan bahwa hampir semua anak gemar jajan disekolahnya, sedangkan hanya $1 \%$ anak yang tidak jajan. Keadaan tersebut seharusnya dapat didukung dengan kualitas jajanan yang baik, artinya jajanan memiliki nilai gizi yang dapat memenuhi kebutuhan tubuh, dan aman dari penggunaan bahan pangan yang tidak diperbolehkan untuk dikonsumsi, baik dari jenisnya atau takarannya. Harapannya kesehatan anak akan tetap terjaga.

Desa Sedayu lawas terletak di kecamatan Brondong, Kabupaten Lamongan. Struktur mata pencarian masyarakat Sedayulawas sebagian besar adalah sebagai petani, namun itu banyak juga yang bekerja sebagai perdagangan makanan, misalnya saja pedagang jajanan yang berkeliling di area sekolah atau area tempat bermain anak-anak. Dari hasil observasi lapangan, ditemukan beberapa pedagang yang menjual makanannya tanpa memperhatikan keamanan pangan dan dampak kesehatan bagi konsumen yang notabennya adalah anak-anak. Misalnya saja ditemukan pedagang "telur gulung" dan "cilor" yang menggunakan minyak goreng yang berwarna hitam, diduga minyak yang digunakannya itu adalah minyak jelantah. Menurut Ardhani dan Lamsiyah (2018) penggunaan minyak jelantah yang dipakai terus menerus akan meningkatkan asam lemak bebas dan menjadikan vitamin, dan asam lemak esensial pada bahan makanan rusak. Penggunaan minyak jelantah juga akan meningkatkan gugus radikal peroksida yang mengikat oksigen, sehingga mengakibatkan oksidasi terhadap jaringan sel tubuh manusia. Jika terus dikonsumsi dalam waktu yang lama akan menyebabkan jantung koroner, kolesterol darah, hipertensi dan menmicu kangker Ardhani dan Lamsiyah (2018). Oleh sebab itu sejalan dengan kondisi tersebut menurut Aminah (2010) penggunaan minyak goreng oleh penjual makanan gorengan, perlu diwaspadai. Belum lagi temuan penggunaan bahan makanan seperti kornet dan sosis yang memiliki warna yang tidak sesuai dengan kriteria produknya, hal ini bisa saja terjadi karena penggunaan pewarna yang tidak sesuai.

Berdasarkan permasalahan tersebut, diperlukan sebuah kegiatan pengabdian masyarakat mengenai penyuluhan kesehatan terkait jajanan yang tidak hanya sehat dan bergizi, namun juga aman dari penggunaan BTP. Selain itu untuk mendukung program pemerintah terkai difersivikasi pangan, penggunaan bahan lokal daerah setempat juga perlu dilakukan. Dari hasil analisis potensi pangan lokal yang pernah dilakukan oleh Miranti, dkk (2018) daerah Sedayulawas memiliki kekayaan berlimpah berupa hasil tambak dan lautnya, mengingat mata pencaharian utamanya adalah nelayan. Adapun pangan tersebut adalah ikan bandeng dan tuna. Selain itu, Sedayulawas juga memiliki potensi pangan dari berkebunan, yaitu pisang dan jagung.

Dari hasil analisis masalah dan situasi tersebut, diselenggarakanlah kegiatan penyuluhan kesehatan melalui pelatihan pengolahan jajanan yang sehat, bergizi, dan aman dengan menggunakan bahan pangan lokal. Harapannya dari kegiatan ini dapat menambah wawasan, pengetahuan, serta 
meningkatkan kesadaran peserta atau masyarakat terkait pengolahan jajanan dengan mengoptimalkan bahan lokal.

\section{METODE}

Pelaksanaan pengabdian kepada masyarakat (PKM) ini bertujuan untuk memberikan keterampilan pengolahan jajanan sehat dan bergizi dengan menggunakan bahan pangan lokal. Dasar pemikiran dalam kegiatan dilakukan menggunakan metode penyuluhan jajanan sehat yang kemudian dilanjutkan dengan pelatihan pengolahan jajanan sehat kepada peserta pelatihan, yaitu 12 orang pedagang makanan, 15 ibu rumah tangga, dan 9 orang kader PKK Desa Sedayulawas. Pelaksanaan pengabdian masyarakat dilakukan seperti bagan berikut: harapannya pengetahuan dan wawasan peserta dalam memilih jajanan yang sehat, bergizi, dan aman akan meningkat. Selanjutnya pada metode kedua yaitu dengan melakukan praktek secara mandiri dengan membuat jajanan sehat yang menggunakan bahan pangan lokal, yaitu jagung, ikan tongkol, dan pisang.

4. Mengukur pengetahuan peserta setelah dilakukan intervensi, yaitu menggunakan post-test dan menilai produk yang dibuat secara mandiri. Selain itu evaluasi kegiatan pengabdian juga dilakukan dengan menyebar angket terkait evaluasi kegiatan dan modul yang diberikan.

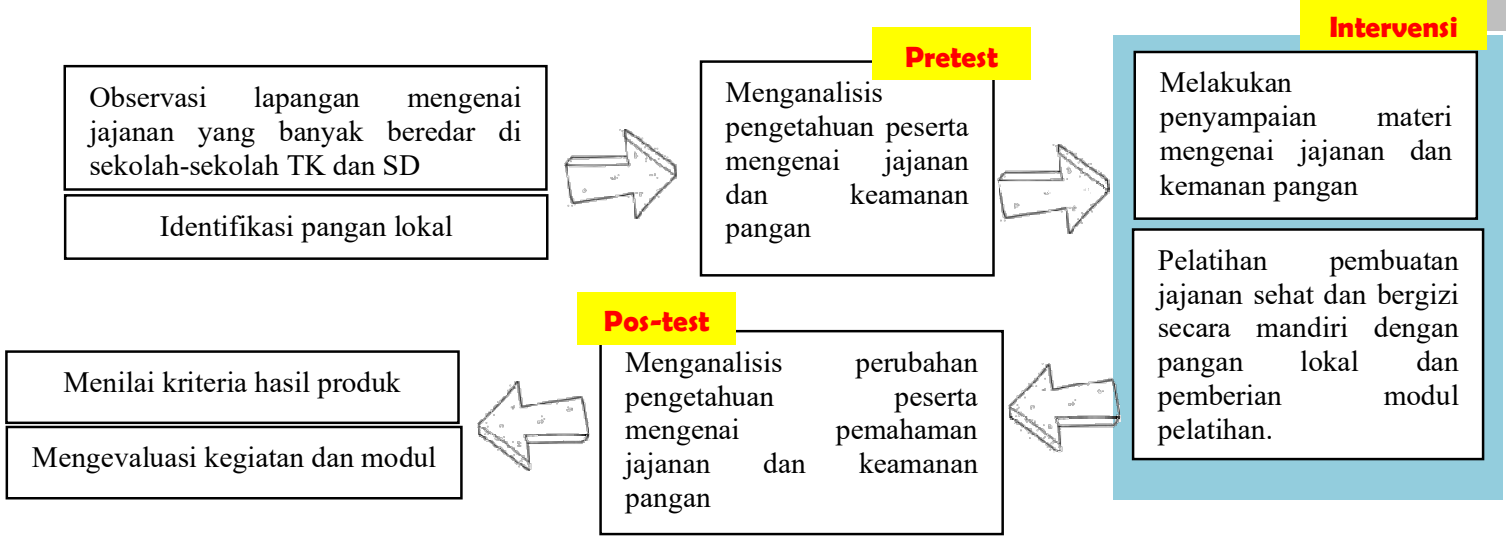

Gambar 1. Kerangka Operasional Pengabdian Kepada Masyarakat

Dari Gambar 1 dapat dilihat pelaksanaan kegiatan pemberdayaan kesehatan melalui pelatihan pembuatan jajanan sehat ini dilakukan dengan metode berikut:

1. Analisis situasi dengan observasi lapangan, yaitu untuk mengetahui kondisi jajanan yang dijajaki oleh pedagang-pedagang diluar sekolah TK dan SD, selain itu dilakukan identifikasi bahan pangan lokal yang memiliki potensi untuk dimanfaatkan secara optimal.

2. Mengukur pengetahuan peserta penyuluhan mengenai jajanan dan kemanan pangan yang beredar melalui pre-test.

3. Melakukan intervensi melalui metode pemberian materi mengenai jajanan sehat, kemanan pangan yang beredar, dan caram memilih jajanan sehat, yang
Evaluasi tingkat pemahaman peserta dibuat dengan membandingkan pengetahuan awal dan setelah intervensi. Pengambilan data tingkat pengetahuan peserta dilakukan dengan menggunakan personal quesionair berupa pre-test dan post-test dengan 15 butir soal. Hasil evaluasi yang didapatkan kemudian dianalisis secara kuantitatif deskriptif.

\section{HASIL DAN PEMBAHASAN}

Pemahaman Jajanan Sehat

Kegiatan pengabdian kepada masyarat yang dilaksanakan pada tanggal 4 November 2018 di Desa Sedayulawas, Lamongan ini bertujuan untuk meningkatkan kesadaran masyarakat terhadap jajanan sehat, bergizi, dan aman dengan meningkatkan kewaspadaan pada keamanan pangan yang beredar, sekaligus untuk membentuk pola pikir masyarakat yang kreatif dan inovaif dalam mengolah jajanan dengan menggunakan pangan lokal. Target dari penyuluhan dan pelatihan ini adalah 
pemahaman mengenai jajanan sehat dan keterampilan pengolahan jajanan sehat, aman, dan bergizi dengan memanfaatkan sumber pangan lokal dan dapat diterapkan dalam keseharian. Hasil yang didapat dari kegiatan PKM adalah berupa pemahaman dan keterampilan pengolahan jajanan sehat, bergizi, dan aman.

Sebelum diberikan pelatihan, peserta diberikan penyuluhan berupa penyampaian materi terkai jajanan sehat, bergisi, dan aman, serta keamanan pangan yang beredar. Namun, untuk mengukur tingkat pemahaman, peserta pelatihan yaitu 36 peserta yang terdiri dari 12 orang pedagang makanan, 15 ibu rumah tangga, dan 9 orang kader PKK Desa Sedayulawas diberikan pre-test sebanyak 15 butir soal. Berikut distribusi pemahaman peserta terhadap jajanan sehat dan kemanan pangan yang beredar berdasarkan penilaian pre-test:

Tabel 1. Distribusi Penilaian Pre-test

\begin{tabular}{ccc}
\hline Rentang Skor & F & \% \\
\hline $33-45$ & 2 & 5,5 \\
$46-58$ & 10 & 27,8 \\
$59-71$ & 11 & 30,5 \\
$72-84$ & 9 & 25 \\
$85-97$ & 4 & 11,2 \\
\hline $\mathbf{n}$ & $\mathbf{3 6}$ & $\mathbf{1 0 0}$ \\
\hline
\end{tabular}

Berdasarkan Tabel 1 dapat dilihat bahwa sebesar $36,2 \%$ peserta memperoleh nilai diatas 71 , yang dapat diartikan tingkat pemahan peserta mengenai jajanan sehat dan kemanan pangan yang beredar sudah baik. Namun sebagian besar yaitu sebanyak $63,8 \%$ memperoleh nilai di bawah 71 yang dapat diartikan tingkat pemahaman peserta dinilai cukup baik tetapi tidak atau belum diimbangi dengan perilaku baik dalam pemilihan jajanan dan bahan pangan yang baik.

Setelah dilakukan pre-test, pesera diberikan inervensi berupa pemaparan materi mengenai jajanan sehat dan keamanan pangan yang beredar. Dari hasil analisis butir soal, kebanyakan peserta tidak mengetahui indikator bahan pangan yang berbahaya dan teknik pengolahan makanan yang benar. Misalnya saja peserta sebagian besar membeli kornet di pasar tanpa memeriksa keamanannya jika dilihat dari warna atau komposisi bahan, penggunaan minyak goreng yang lebih dari tiga kali, atau pemanasan makanan yang berulang-ulang. Berdasarkan permasalahan tersebut harapannya dari penyuluhan ini akan memberikan perubahan perilaku, hal ini sejalan dengan Subejo (2010) bahwa tujuan penyuluhan adalah terjadinya perubahan perilaku dikalangan masyarakat agar mereka tahu, mau dan mampu melakukan perubahan demi tercapainya peningkatan produksi, pendapaan atau keuntungan dna perbaikan kesejaheraan.

Pemaparan materi disampaikan oleh Dra. Niken Purwidiani, M.Pd. selama lima belas menit. Penyampaian materi menggunakan bantuan hand out yang diberikan kepada peserta, tujuannya agar peserta dapat memahami materi yang disampaikan mwnjadi lebih baik. Selama penyampaian materi, peserta terlihat antusias, hal ini dilihat dari banyaknya peserta penyuluhan yang bertanya untuk memperluas dan memperdalam materi. Setelah materi disampaikan, peserta kembali diberikan post-test dengan model soal yang sama, hanya saja penomeran diacak. Beriku merupakan hasil post-test peserta terkait jajanan sehat dan kemanan pangan yang beredar.

Tabel 2. Distribusi Penilaian Post-test

\begin{tabular}{ccc}
\hline Rentang Skor & F & \% \\
\hline $33-45$ & 0 & 0 \\
$46-58$ & 0 & 0 \\
$59-71$ & 13 & 36,1 \\
$72-84$ & 9 & 25 \\
$85-97$ & 14 & 38,9 \\
\hline $\mathbf{N}$ & $\mathbf{3 6}$ & $\mathbf{1 0 0}$ \\
\hline
\end{tabular}

. Berdasarkan Tabel 2 dapat diperoleh informasi mengenai hasil distribusi nilai posttest, yaitu jika dibandingkan dengan Tabel 1 terjadi peningkatan pada pemahaman peserta yaitu sebesar $14,26 \%$. Nilai peserta yang di bawah 71 hanya $36,1 \%$, sedangkan yang di atas 71 sebanyak $63,9 \%$. Hasil evaluasi post test menunjukkan pengetahuan peserta mengenai jajanan sehat, bergizi, dan aman, serta keamanan pangan yang beredar setelah kegiatan penyuluhan, terjadi peningkatan yang lebih baik dari nilai pre test. Dengan adanya peningkatan pemahaman peserta, artinya penyuluhan kesehatan mengenai jajanan sehat ini sesuai dengan harapan, yaitu terjadinya peningkatan pemahaman. Kondisi ini sesuai dengan pendapat Sukmadinata (2009) yang menjelaskan bahwa penyuluhan kesehatan berpengaruh terhadap perilaku sebagai hasil jangka menengah (intermediate impact), yaitu perubahan tingkat 
pengetahuan, kecakapan, kemampuan, sikap dan motif tindakan

\section{Pelatihan Pembuatan Jajanan Sehat, Bergizi, dan Aman}

Rancangan kegiatan PKM ini selain dilaksanakann penyuluhan dengan penyampaian materi, juga dilakukan pelatihan pembuatan jajanan sehat, bergizi dan aman secara mandiri oleh peserta pelatihan sebanyak 36 peserta yaitu terdiri dari 12 orang pedagang makanan, 15 ibu rumah tangga, dan 9 orang kader PKK Desa Sedayulawas. Tujuan dilakukannya pelatihan pembuatan jajanan sehat dengan menggunakan pangan lokal ini, selain bentuk dari diversivikasi pangan juga untuk meningkatkan pasrtisipasi masyarakat, terutama pelaku usaha untuk menyediakan jajanan sehat, bergizi dan aman. Pelatihan yang dilakukan adalah dengan membuat jajanan sehat, bergizi, dan aman yang menggunakan pangan lokal, yaitu pisang yang diolah menjadi nugget, bandeng yang diolah menjadi sempol, ikan tuna yang diolah menjadi takoyaki, dan jagung yang diolah menjadi susu jagung. Pelatihan pembuatan jajanan sehat dilakukan oleh Mauren GM, M.Pd, IF. Romahdoni, M.Pd, dan Dra. Niken Purwidiani, M.Pd.

Peningkatan pemahaman mengenai jajanan sehat dan keamanan pangan yang beredar berdasarkan Tabel 1 dan 2 perlu ditingkatkan lagi, karena adanya pelatihan

\begin{tabular}{ccccc}
\hline \multirow{2}{*}{ Kelompok } & \multicolumn{4}{c}{ Kriteria hasil produk } \\
\cline { 2 - 5 } & $\begin{array}{c}\text { Nugget } \\
\text { pisang }\end{array}$ & $\begin{array}{c}\text { Susu } \\
\text { jagung }\end{array}$ & $\begin{array}{c}\text { Takoyaki } \\
\text { isi tuna }\end{array}$ & $\begin{array}{r}\text { Se } \\
\text { band }\end{array}$ \\
\hline Kelompok 1 & 4 & 3 & 4 \\
Kelompok 2 & 3 & 3 & 3 \\
Kelompok 3 & 4 & 4 & 3 \\
Kelompok 4 & 3 & 4 & 2 \\
Kelompok 5 & 4 & 3 & 4 \\
Kelompok 6 & 4 & 4 & 3 \\
\hline
\end{tabular}

pengolahan makanan dapat merubah perilaku peserta. Hal ini sama seperti pendapat Notoatmodjo (2007) yang maparkan bahwa pengetahuan merupakan ranah yang sangat penting dalam membentuk tindakan seseorang. Pencapaian gizi seimbang masih merupakan permasalahan yang belum terselesaikan, hal ini disebabkan karena kondisi ekonomi seseorang yang masih kurang dan terbatasnya pengetahuan mengenai nilai gizi dari makanan (Irianto, 2004). Sehingga dengan pelatihan pembuatan jajanan sehat, bergizi, dan aman ini diharapkan dapat menstimulasi peserta dalam meningkatkan sikap atau kesadaran diri untuk merubah perilakunya dalam mengolah makanan.

Peserta kegiatan dalam pelatihan pembuatan jajanan sehat ini menunjukkan antusias yang sangat baik. Hal dapat dilihat dari antusias peserta selama mengolah makanan. Sebanyak $87,8 \%$ peserta menyukai metode praktek langsung karena dirasa lebih mudah dipahami dan memberikan inspirasi untuk mengolah pangan lokal seperti nugget pisang, susu jagung, takoyaki isi tuna dan sempol bandeng. Pelatihan pembuatan jajanan sehat, bergizi, dan aman yang dilakukan secara mandiri ini juga menunjukkan kemampuan peserta pelatihan yang terdiri dari ibu rumah tangga, kader PKK, dan pelaku usaha dalam mengolah produk lokal, selain itu kreativitas peserta juga akan terlatih. Dari kegiatan ini pengetahuan, keterampilan, dan motivasi peserta untuk membuat jajanan yang sehat, bergizi, dan aman akan meningkat. Berikut merupakan rata-rata nilai pembuatan jajanan sehat, bergizi, dan aman.

Tabel 3. Penilaian Produk Pelatihan

Dari Tabel 3 dapat dilihat bahwa keterampilan mengolah produk yang dinilait dari kriteria hasil produk, sanitasi dan hygiene, serta penyajian produk pada setiap kelompok rata-rata

\begin{tabular}{lccc} 
mpol & $\begin{array}{c}\text { Sanitasi } \\
\text { \& } \\
\text { hygiene }\end{array}$ & $\begin{array}{c}\text { Penyajian } \\
\text { produk }\end{array}$ & $\sum$ \\
4 & 3 & 3 & 3,5 \\
4 & 3 & 4 & 3,3 \\
4 & 2 & 4 & 3,5 \\
4 & 3 & 3 & 3,2 \\
4 & 2 & 4 & 3,5 \\
4 & 3 & 4 & 3,7 \\
\hline
\end{tabular}

\section{adalah 3,45 dengan rentang skor $1-4$, artinya keterampilan tergolong baik. Namun masih ada yang harus diperhatikan dan}

ditingkatkan kembali, yaitu sanitasi dan hygiene dalam mengolah makanan. Misalnya saja tidak bercakap-cakap selama mengolah bahan makanan, penyimpanan makanan, dan penjamahan makanan yang tidak menggunakan alat.

Setelah dilakukan pelatihan, peserta diberikan beberapa pertanyaan terkait pengolahan jajanan sehat, bergizi, dan aman berbasis pangan lokal sebagai penguatan dan refleksi pelatihan. Hasilnya peserta sangat antusias dalam menjawab pertanyaan secara langsung. Hal ini sesuai dengan pernyataan Helmy, dkk (2013) bahwasa tujuan penyuluhan 
adalah untuk menumbuhkan perubahanperubahan yang menyangkut tingkat pengetahuan, kecakapan atau sikap peserta penyuluhan dan pelatihan merupakan upaya yang digunakan untuk meningkatkan keterampilan yang dibutuhkan untuk melaksanakan pekerjaan sekarang (Panggabean , 2004) Peningkatan pengetahuan merupakan salah satu indikator efektifnya penyuluhan.

$$
\text { Dari kegiatan penyuluhan dan }
$$
pelatihan, upaya lanjutan perlu dilakukan untuk mendukung generasi yang sehat dan cerdas, maka tahap selanjutnya perlu dukungan pemerintah dengan memberikan penyuluhan dan pelatihan yang serupa kepada para pelaku usaha. Selain itu pemerintah bersama masyarakat perlu meningkatkan kesadaran terhadap kemanan pangan yang beredar dengan selektif memilih bahan pangan atau memanfatkan pangan lokal lainnya. Pada program pelatihan juga diharapkan dapat memberikan inovasi-inovasi yang baru terkait jajanan sehat lainnya, serta pengemasan yang lebih menarik.

\section{KESIMPULAN}

Kegiatan PKM telah diselenggarakan dengan baik dan berjalan lancar. Dari kegiatan tersebut, hasil pre-test peserta menunjukan bahwa pengetahuan awal mengenai jajanan sehat, bergizi, dan aman, serta keamanan pangan yang beredar, sebanyak $63,8 \%$ mendapatkan skor di bawah 71. Nilai tersebut dapat diartikan sebagian besar peserta memiliki pengetahuan yang kurang terhadap jajanan sehat, bergizi, dan aman, serta keamanan pangan yang beredar. Namun setelah dilakukan intervensi, hasil post-test menunjukan peningkatan sebesar $14,26 \%$, yaitu peserta dengan skor di atas 71 sebanyak $63,9 \%$. Penilaian produk pelatihan peserta juga dinilai, nillai rata-rata produk adalah 3,45 yang artinya sudah baik dan sesuai dengan kriteria hasil. Sebanyak $87,8 \%$ peserta menyukai metode praktek langsung karena dirasa lebih mudah dipahami dan memberikan inspirasi untuk mengolah pangan lokal.

\section{REFERENSI}

Aminah, S. 2010. Bilangan Peroksida Minyak Goreng Curah Dan Sifat Organoleptik Tempe Pada PengulanganPenggorengan. Semara ng: Jurnal Pangan dan Gizi. Vol. 01., Hal 7-13.
Ardhany, Syahrida Dian dan Lamsiyah. 2018. Tingkat Pengetahuan Pedagang Warung Tenda Di Jalan Yos Sudarso Palangkarayatentang Bahaya Penggunaan Minyak Jelantah Bagi Kesehatan. Jurnal Surya Medika Volume 3 No. 2 (2018) hal. 62-68.

Badan Pengawas Obat dan Makanan Republik Indonesia (BPOM RI). 2011. Laporan Tahunan Badan Pengawas Obat dan Makanan Republik Indonesia Tahun 2010. Jakarta.

Handayani, dkk. 2018. Pelatihan Pembuatan Bekal Sehat Secara Mandiribagi Anak Usia Sekolah Di Sdn Margorejo V Surabaya. Communiy Development Journal, UNUSA Volume 2 No. 1 (2018) ISSN: 2580-5282, E-ISSN: 2580-5290.

Helmy, dkk. 2013. Hubungan Kompetensi Penyuluh Dengan Karakteristik Pribadi, Persepsi Penyuluh Terhadap Dukungan Kelembagaan Dan Persepsi Penyuluh Terhadap Sifat Inovasi Cyber Extensión. Jurnal Agro Ekonomi, Volume 31 No. 1 Mei 2013 Hal. 1-18.

Irianto, Agus. 2004. Pengantar Pangan dan Gizi. Jakarta: Penebar Swadaya.

Miranti, Mauren Gita, dkk. 2018. Pembuatan Kue Kering Berbasis Kearifan Lokal Di Kecamaan Brondong-Lamongan (Kajian Respon Pelatihan). Jurnal ABDI Vol. 3 No. 2 Januari 2018, hal. 102-107 p-ISSN: 2460-5514 e-ISSN: 25026518.

Notoatmodjo, Soekidjo. 2007. Pendidikan dan Perilaku Kesehatan. Jakarta: Rineka Cipta.

Panggabean, S. M. 2004. Manajemen Sumber Daya Manusia. Bogor: Ghalia Indonesia.

Sukmadinata, Nana Syaodih. 2009. Metode penelitian Pendidikan. Bandung: Remaja Rosdakarya.

Subejo. (2010). Penyuluhan Pertanian Terjemahan Dari Agriculture. Extention (edisi 2). Jakarta. 